\title{
A Review of Phytochemistry and Pharmacological Properties of Threatened Croton Species Used as Herbal Medicines in East Africa
}

\author{
Alfred Maroyi
}

Medicinal Plants and Economic Development Research Centre, Department of Botany, University of Fort Hare, Alice, South Africa

\begin{abstract}
Some rare and threatened Croton species have a long history of medicinal usage in East Africa. The objective of this study was to review the phytochemistry and pharmacological properties of five Croton species that are threatened with extinction in East Africa but widely used as herbal medicines in the region. Information on medicinal uses, phytochemistry and pharmacological properties of C. alienus, C. dictyophlebodes, C. jatrophoides, C. megalocarpoides and C. talaeporos was obtained from databases such as Scopus, Web of Science, Science Direct, Google Scholar, PubMed, BioMed Central (BMC), Springerlink and Scielo. Other sources of information included scientific publications, conference proceedings, theses, books and book chapters obtained from libraries. Literature search revealed that the bark, fruits, leaves and roots of these five Croton species are commonly used as traditional medicines for gastrointestinal disorders, colds and influenza, body pains and weaknesses and intestinal worms. Phytochemical compounds isolated from these species include alkaloids, anthraquinones, diterpenoids, esters, flavonoids, furanoditerpenoids, limonoids, methylcyclohexanes, phenolics, steroids, tannins and triterpenoids. Pharmacological studies indicate that these species have antifungal, anti-leishmanial and insect antifeedant activities. Preliminary phytochemical and pharmacological research done so far on Croton species is promising, but too general to corroborate some of the medicinal uses of the species.
\end{abstract}

Keywords: Croton alienus, Croton dictyophlebodes, Croton jatrophoides, Croton megalocarpoides, Croton talaeporos.

\section{INTRODUCTION}

Some rare and threatened plant species are known to have unique chemical compounds characterized by potent biological activities. The genus Warburgia Engl. is a typical example [1-5], with most of its species having long history of ethnomedicinal uses in east, central and southern Africa. Due to the popularity of Warburgia species as sources of ethnomedicines, most species of the genus are severely over-harvested throughout their distributional ranges. It is within this context that a review of phytochemistry and pharmacological properties of five Croton L. species that are threatened with extinction in East Africa but widely used as herbal medicines in the region was carried out. Genus Croton is a member of the Euphorbiaceae or spurge family. Presence of biologically active natural products in some members of the Euphorbiaceae family contributed to many members of the family being widely used as herbal medicines in Africa, Asia and South America [6]. Some medicinal applications of Croton species include their use in the treatment of cancer, constipation, diabetes, digestive problems, dysentery, external wounds, fever,

*Address correspondence to this author at the Medicinal Plants and Economic Development Research Centre, Department of Botany, University of Fort Hare, Alice, South Africa; Tel: +27719600326; E-mail: amaroyi@ufh.ac.za

ISSN: 2223-3806 / E-ISSN: 1927-5951/18 hypercholesterolemia, hypertension, inflammation, intestinal worms, malaria, pain, ulcers and weight-loss [6]. At least 15 Croton species are used as herbal medicines in East Africa [7-16], and among these are five species that are threatened or are of conservation concern (Table 1).

Croton alienus Pax is a shrub or small tree restricted to humid areas of upland evergreen or secondary forest in central Kenya $[17,18]$. Croton dictyophlebodes A. R.-Sm. is a deciduous mediumsized to large tree up to 20 metres tall restricted to the West Usambara Mountains and montane dry evergreen forest in Tanzania [11,17]. Croton jatrophoides Pax is a monoecious or dioecious tree up to $18 \mathrm{~m}$ tall recorded in forest edges and clearings, riverine and dry coastal forest in Tanzania $[11,17]$, but also said to occur in south-east Kenya and Central African Republic [13]. Croton megalocarpoides Friis \& M. G. Gilbert is a monoecious shrub to small tree growing up to $8 \mathrm{~m}$ tall recorded in semi-evergreen coastal forests, bushland and mountainous areas in Kenya, Mozambique, Somalia, Tanzania $[17,19]$. Croton talaeporos A. R.-Sm. is a monoecious or sometimes dioecious many-stemmed small or large tree up to $10 \mathrm{~m}$ tall recorded in coastal bushland and wooded grassland in Kenya and southern Somalia[17]. The present review is aimed at documenting the

() 2018 SET Publisher 
Table 1: Croton Species in East Africa that are Threatened or are of Conservation Concern

\begin{tabular}{|c|c|c|c|c|}
\hline Croton species & IUCN status & Distribution & Conservation concerns and threats & References \\
\hline C. alienus & $\begin{array}{l}\text { Endangered } \\
\qquad(\mathrm{Bl}+2 \mathrm{c})\end{array}$ & Kenya & $\begin{array}{l}\text { Habitat transformation and loss result in small and relatively } \\
\text { isolated subpopulations. Species population is negatively } \\
\text { affected as its habitat is converted to agricultural land and } \\
\text { human settlement. As an endemic species characterized by } \\
\text { extreme fluctuations in extent of occurrence and area of } \\
\text { occupancy, over-collection will pause a major threat to the } \\
\text { species. }\end{array}$ & {$[18,20]$} \\
\hline C. dictyophlebodes & $\begin{array}{l}\text { Vulnerable } \\
\qquad(\mathrm{B} \mid+2 \mathrm{~b})\end{array}$ & Tanzania & $\begin{array}{l}\text { The species population is continuing to decline due to } \\
\text { habitat transformation and loss. Population size negatively } \\
\text { affected by decreasing area, extent and/or quality of habitat } \\
\text { and decreasing number of mature individuals. }\end{array}$ & [20] \\
\hline C. jatrophoides & $\begin{array}{l}\text { Vulnerable } \\
\qquad(\mathrm{B} \mid+2 \mathrm{~b})\end{array}$ & $\begin{array}{l}\text { Kenya, } \\
\text { Tanzania }\end{array}$ & $\begin{array}{c}\text { Just like } C \text {. dictyophlebodes, the species population is } \\
\text { continuing to decline due to habitat transformation and loss. } \\
\text { Population size negatively affected by decreasing area, } \\
\text { extent and/or quality of habitat and decreasing number of } \\
\text { mature individuals. }\end{array}$ & [20] \\
\hline C. megalocarpoides & $\begin{array}{c}\text { Near } \\
\text { threatened }\end{array}$ & $\begin{array}{l}\text { Kenya, } \\
\text { Mozambique, } \\
\text { Somalia, } \\
\text { Tanzania }\end{array}$ & $\begin{array}{c}\text { Evaluations carried out in Kenya and Tanzania indicate that } \\
\text { the species is likely to become at risk of extinction in the } \\
\text { near future. }\end{array}$ & {$[18,20]$} \\
\hline C. talaeporos & $\begin{array}{l}\text { Near } \\
\text { threatened }\end{array}$ & Kenya, Somalia & $\begin{array}{c}\text { Croton talaeporos is naturally rare in Somalia, and therefore, } \\
\text { the species is likely to become at risk of extinction in the } \\
\text { near future. }\end{array}$ & [20] \\
\hline
\end{tabular}

ethnomedicinal uses, phytochemistry and pharmacological properties of five Croton species that are threatened with extinction in East Africa. Results of this study are expected to reveal research challenges and perspectives required to address the dilemma associated with popular herbal medicines that are threatened due to anthropogenic activities in the tropics. I hope that this information will highlight the importance of the genus and will provide baseline information for future researchers intending to do further work on genus Croton.

\section{MATERIALS AND METHODS}

The following five Croton species, C. alienus (Mildbraedia balboana Chiov.), C. dictyophlebodes, C. jatrophoides, C. megalocarpoides and C. talaeporos (C. integrifoliussensu T.S.K.) were used as the keywords in searching the major databases including Web of Science, Scopus, Google Scholar, Science Direct, BioMed Central (BMC), PubMed, Scielo and Springerlink documenting their ethnomedicinal uses, ethnobotany, ethnopharmacology, pharmacology, phytochemistry and therapeutic value of the species. Additional literature, including pre-electronic literature such as dissertations, theses, international journal articles, scientific reports from international, regional and national organizations, conference papers and books were sourced from the University of Fort Hare library in South Africa. This review draws heavily on the research results published in international journals (25), books (six), book chapters (two), dissertations and theses (two) and conference proceedings (two).

\section{Ethnomedicinal Uses}

A total of 14 human diseases and ailments are treated with herbal concoctions prepared from Croton species (Table 2). Gastro-intestinal disorders (stomachache and stomach complaints), colds and influenza, body pains and weaknesses, and intestinal worms are the most commonly treated human diseases (Figure 1). According to Gachathi [12], C. alienusis used as herbal medicine for general body weaknesses in Kenya. Fruit infusions and decoctions of $C$. dictyophlebodes are taken orally as remedy for intestinal worms in Tanzania [11]. Croton jatrophoidesis used as herbal medicine for fever, headache and influenza in Kenya [12]. In Tanzania, fruit and root infusions and decoctions of $C$. jatrophoides are taken orally as remedies for colds, intestinal worms and stomachache $[7,11,21]$. Ethnobotanical research by Kiringe [10] revealed that $C$. megalocarpoides is used as herbal medicine in Kenya to induce vomiting, induce bile release if one is suspected to have malaria and as remedy for stomachache. In Kenya, leaf and root infusions of $C$. talaeporosare used as remedies for body pains, body swellings, colds, inflammation and stomach complaints $[8,9,13]$ and seeds are used as a laxative in Somalia [22]. 
Table 2: Ethnomedicinal uses of Croton Species that are Threatened with Extinction in East Africa

\begin{tabular}{|c|c|c|c|}
\hline Use & Plant parts used & Country practiced & References \\
\hline \multicolumn{4}{|l|}{ C. alienus } \\
\hline Body weaknesses & Not specified & Kenya & {$[12,15]$} \\
\hline \multicolumn{4}{|l|}{ C. dictyophlebodes } \\
\hline Intestinal worms & Fruit decoction or infusion taken orally & Tanzania & {$[11]$} \\
\hline \multicolumn{4}{|l|}{ C. jatrophoides } \\
\hline Colds & Root decoction and infusion taken orally & Tanzania & {$[7,11,21]$} \\
\hline Fever & Not specified & Kenya & [7] \\
\hline Headache & Not specified & Kenya & [7] \\
\hline Influenza & Not specified & Kenya & [7] \\
\hline Intestinal worms & Fruit and root decoction or infusion taken orally & Tanzania & {$[7,11,21]$} \\
\hline Stomachache & Root decoction and infusion taken orally & Tanzania & {$[7,11,21]$} \\
\hline \multicolumn{4}{|l|}{ C. megalocarpoides } \\
\hline Induce vomiting & Not specified & Kenya & {$[10]$} \\
\hline Induce bile release & Not specified & Kenya & {$[10]$} \\
\hline Stomachache & Not specified & Kenya & {$[10]$} \\
\hline \multicolumn{4}{|l|}{ C. talaeporos } \\
\hline Body pains & Leaf and root infusions & Kenya & [9] \\
\hline Body swellings & Leaf and root infusion applied on affected body part & Kenya & {$[8]$} \\
\hline Colds & Root infusion taken orally & Kenya & {$[13]$} \\
\hline Inflammation & Leaf and root infusion applied on affected body part & Kenya & [9] \\
\hline Laxative & Seed infusion taken orally & Somalia & {$[22]$} \\
\hline Stomach complaints & Root infusion taken orally & Kenya & [13] \\
\hline
\end{tabular}

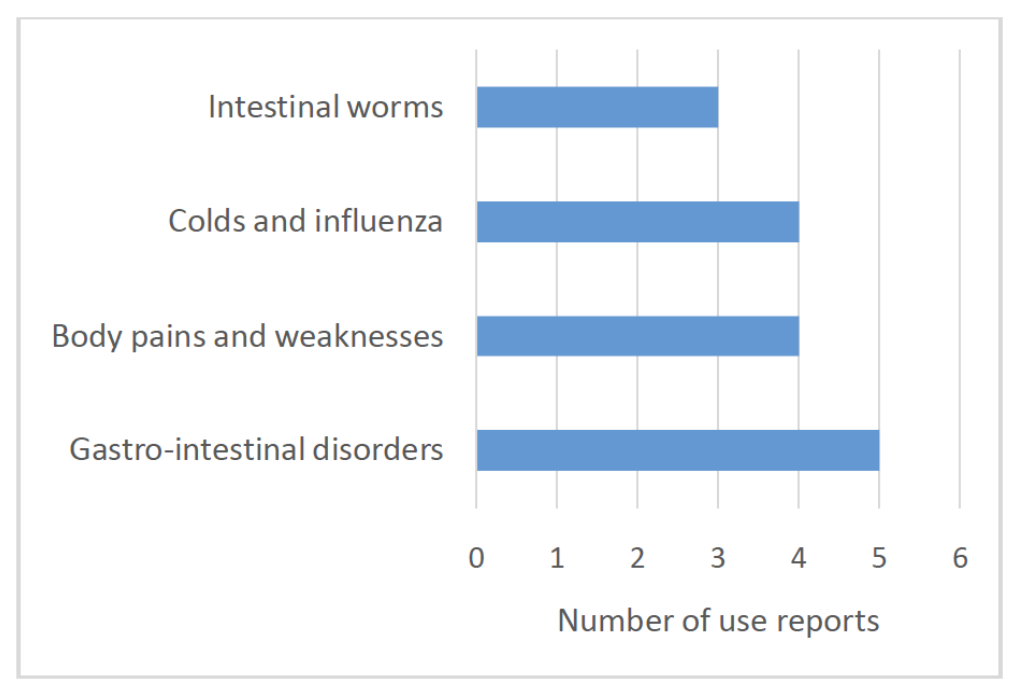

Figure 1: Medicinal uses of threatened Croton species in East Africa.

\section{Phytochemistry and Pharmacological Activities}

These five Croton species have high pharmaceutical value due to alkaloids $[14,15]$, diterpenoids [14,16], esters [14,15], furanoditerpenoids [23,24], limonoids [25-29], methylcyclohexane $[14,15,30]$, steroids [15] and triterpenoids [14,15] that have been isolated from bark, leaves and roots. 
Chhabra et al. [30] isolated crotepoxide, methylcyclohexane from a stem bark of $C$. alienus (Table 3). Ndunda [14] and Ndunda et al. [15] isolated methylcyclohexane, pentacyclic triterpenoid, ester, alkaloid and steroid compounds, namely crotepoxide, dideacetylcrotepoxide, monodeacetylcrotepoxide, $\alpha-$ senepoxide, $\beta$-senepoxide, (+)-(2S, 3R)-diacetoxy-1benzoyloxymethylenecyclohex-4, 6-diene, acetyl aleuritolic, alienusolin, benzyl benzoate, crotonimide C, julocrotine and 24-ethylcholesta-4,22-dien-3-one24ethylcholesta-4,22-dien-3-one24-ethylcholesta-4,22dien-3-one from leaves and roots of $C$. alienus (Table 3). Limonoids, namely dumsin, zumsin, zumketol, zumsenin, zumsenol, dumnin, dumsenin, musidunin and musiduol were isolated from root bark of $C$. jatrophoides [25-29] (Table 3). Mbwambo et al. [23] and Magadula et al. [24] isolated four furano diterpenoids namely, isoteucvin, jatropholdin, penduliflaworosin and teucvin from roots of $C$. jatrophoides (Table 3). Ndunda [14] and Ndunda et al. [16] isolated triterpenoids, abietane, ent-clerodane and trachylobane diterpenoids, namely acetylaleuritolic acid, lupeol, isolophanthin $A$, isolophanthin $E$, abietic acid, crotocorylifuran, 12-epi-crotocorylifuran, $8 \beta$ hydroxycrotocorylifuran, crotocorylifuran-2-one, 7, 8dehydrocrotocorylifuran, megalocarpoidolide A, megalocarpoidolide $B$, megalocarpoidolide $C$, megalocarpoidolide $D$, megalocarpoidolide $E$, megalocarpoidolide $F$, megalocarpoidolide $G$, megalocarpoidolide $\mathrm{H}, 3 \alpha$, 18-dihydroxytrachylobane, ent-trachyloban-18-ol, ent-trachyloban-18-oic acid and ent-3a-hydroxytrachyloban-18-al (Table 3).

Phytochemical screening of the aqueous and methanol extracts of $C$. alienus and $C$. megalocarpoides showed trace elements of

Table 3: Phytochemical Compounds Isolated from Croton Species that are Threatened with Extinction in East Africa

\begin{tabular}{|c|c|c|}
\hline Compound & Plant parts used & References \\
\hline \multicolumn{3}{|l|}{ C. alienus } \\
\hline \multicolumn{3}{|l|}{ Methylcyclohexanes } \\
\hline Crotepoxide & Leaves, roots, stem bark & {$[14,15,30]$} \\
\hline $\begin{array}{l}\text { Dideacetylcrotepoxide, monodeacetylcrotepoxide, } \alpha \text {-senepoxide, } \beta \text {-senepoxide, }(+)-(2 S \text {, } \\
\text { 3R)-diacetoxy-1-benzoyloxymethylenecyclohex-4, 6-diene }\end{array}$ & Leaves, roots & {$[14,15]$} \\
\hline \multicolumn{3}{|l|}{ Triterpenoid } \\
\hline Acetyl aleuritolic & Leaves, root & {$[14,15]$} \\
\hline \multicolumn{3}{|l|}{ Esters } \\
\hline Alienusolin, benzyl benzoate & Leaves, root & {$[14,15]$} \\
\hline \multicolumn{3}{|l|}{ Alkaloids } \\
\hline Crotonimide $\mathrm{C}$, julocrotine & Leaves, root & {$[14,15]$} \\
\hline \multicolumn{3}{|l|}{ Steroid } \\
\hline 24-ethylcholesta-4,22-dien-3-one & Leaves, root & [15] \\
\hline \multicolumn{3}{|l|}{ C. jatrophoides } \\
\hline \multicolumn{3}{|l|}{ Limonoids } \\
\hline $\begin{array}{c}\text { Dumsin, zumsin, zumketol, zumsenin, zumsenol, dumnin, dumsenin, musidunin and } \\
\text { musiduol }\end{array}$ & Root bark & [25-29] \\
\hline \multicolumn{3}{|l|}{ Furano diterpenoids } \\
\hline Isoteucvin, jatropholdin, penduliflaworosin, teucvin & Root & {$[23,24]$} \\
\hline \multicolumn{3}{|l|}{ C. megalocarpoides } \\
\hline \multicolumn{3}{|l|}{ Triterpenoids } \\
\hline Acetylaleuritolic acid, lupeol & Roots & {$[14,16]$} \\
\hline \multicolumn{3}{|l|}{ Abietane diterpenoids } \\
\hline Isolophanthin A, isolophanthin E, abietic acid & Roots & {$[14,16]$} \\
\hline \multicolumn{3}{|l|}{ Ent-clerodane diterpenoids } \\
\hline 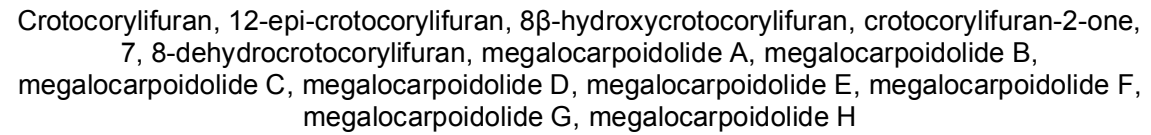 & Roots & {$[14,16]$} \\
\hline \multicolumn{3}{|l|}{ Trachylobane diterpenoids } \\
\hline $\begin{array}{l}\text { 3a, 18-dihydroxytrachylobane, ent-trachyloban-18-ol, ent-trachyloban-18-oic acid, ent-3a- } \\
\text { hydroxytrachyloban-18-al }\end{array}$ & Roots & {$[14,16]$} \\
\hline
\end{tabular}


anthraquinones, tannins, phenolics and flavonoid [14]. The methanol extracts of the stem barks of $C$. megalocarpoides were found to have very low total phenolic content (TPC; $1.89+0.02 \%-1.14+0.01 \%$ $\mathrm{w} / \mathrm{w}$ equivalent of gallic acid). These extracts were additionally found to have low antioxidant potential with half maximal inhibitory concentration $\left(\mathrm{IC}_{50}\right)$ value which was > $1000 \mu \mathrm{g} / \mathrm{ml}$ and ascorbic acid exhibited $\mathrm{IC}_{50}$ value of $9.51 \mu \mathrm{g} / \mathrm{ml}$ [14]. The same author also evaluated antifungal activities of aqueous and methanol root extracts of $C$. alienus against Aspergillus niger, Cryptococcus neoformans and Candida albicans with nystatin and dimethyl sulfoxide (DMSO) as positive and negative controls, respectively. The root and stem bark aqueous extracts of $C$. alienus were active towards $C$. albicans at the lowest concentration of $25 \mathrm{mg} / \mathrm{mL}$ tested [14]. The compound enttrachyloban-19-oic acid has been found to have antimicrobial activity against methicillin resistant Staphylococcus aureus and Mycobacterium smegmatis [31]. Both ent-trachyloban-19-oic acid and its derivative, ent-trachyloban-19-oic methyl ester inhibited the growth of Streptococcus mutans (associated with caries) at 8.9 and $70.5 \mu \mathrm{g} / \mathrm{mL}$ respectively and had biofilm formation by the same bacteria at 32.5 and $125.0 \mu \mathrm{g} / \mathrm{mL}$ respectively [32]. These findings somehow corroborate the traditional use of Croton species as herbal medicine against fungal infections.

Ndunda [14] evaluated in vitro anti-leishmanial activities of $C$. alienus bark, leaf and root extracts using alamar blue assay by testing growth of Leishmania donovani promastigotes with pentamidine and amphotericin B as positive controls. The methanol:dichloromethane (1:1) leaf extract showed activity against Leishmania donovani with $\mathrm{IC}_{50}$ value of $80 \mu \mathrm{g} / \mathrm{mL}$ [14]. Compound crotepoxide isolated from Croton macrostachyus Hochst. \& Delile demonstrated ant-leishmanial activities against promatigotes and amastogotes of Leishmania aethiopica which were comparable to reference ant-leishmanial drugs, amphotericin B and mittefosine [33]. Compound aleuritolic acid isolated from Discoglypremma caloneura (Pax) Prain (family Euphorbiaceae) exhibited significant anthelminthic activities on the vitality of adult male worms of Onchocera gutturosa [34]. Although none of the Croton species documented in this study is used against visceral leishmaniasis, research by Tajebe et al. [35] showed that visceral leishmaniasis patients are often co-infected with intestinal parasites. Research conducted by Kokwaro [7], Lovett et al. [11] and Watt and Breyer-Brandwijk [21] showed that C. dictyophlebodes and $C$. jatrophoides are widely used in Tanzania as herbal medicines against intestinal worms.
Nihei et al. [26-29] evaluated insect antifeedant activities of compounds dumnin, dumsenin, musidunin, musiduol, zumketol and zumsinisolated from $C$. jatrophoides using leaf disk assay and second-instar larvae of Pectinophora gossypiella and Spodoptera frugiperda as test organisms. The two compounds showed antifeedant activities with 50\% protective concentration $\left(\mathrm{PC}_{50}\right), \mathrm{PC}_{90}$ and $\mathrm{PC}_{95}$ values ranging from $0.5 \mu \mathrm{g} / \mathrm{mL}$ to $36 \mu \mathrm{g} / \mathrm{mL}$ against the larvae of Pectinophora gossypiella and Spodoptera frugiperda [26-29]. Similarly, Kinyoda et al. [36] evaluated antifungal activities of hexane, ethyl acetate and methanol root, bark and leaf extracts of $C$. jatrophoides against Fusarium oxysporum f. sp. lycopersici using disc diffusion assay. Fusarium oxysporum f. sp. lycopersici causes soil borne disease in tomatoes (Solanum lycopersicum L.) both in the field and greenhouses. The extracts exhibited some activities with growth inhibition zones ranging from $4.17 \mathrm{~mm}$ to $8.61 \mathrm{~mm}$ and all extracts exhibiting the minimum inhibition concentration (MIC) of $50 \mathrm{mg} / \mathrm{ml}$ [36].Further studies are required to establish mechanisms of control against Fusarium oxysporum f. sp. lycopersici, Pectinophora gossypiella and Spodoptera frugiperda, as $C$. jatrophoides can provide an effective control option where synthetic products are unavailable or unaffordable particularly in remote rural areas in East Africa.

\section{CONCLUSION}

The present study summarizes ethnomedicinal uses, phytochemistry and pharmacological properties of the five Croton species that are threatened with extinction in East Africa. There are similarities and overlaps in terms of ethnomedicinal uses, phytochemistry and pharmacological properties. Future studies should try to establish whether there are phytochemical compounds and pharmacological properties that could be used to distinguish these species. The contemporary research involving Croton species is promising, but it is too preliminary and sometimes too general to be used to explain and support some of the ethnomedicinal uses of the species. For example, C. alienus, C. jatrophoides and $C$. talaeporos are used as remedies for pain and inflammation, therefore, there is need for detailed antiinflammatory and analgesic activities of both crude extracts and compounds of the species. Future studies should also focus on toxicity and safety evaluation of the crude extracts and chemical compounds isolated from the species. Detailed in vitro and in vivo genotoxic studies of these species is required to confirm the 
ethnomedicinal and pharmaceutical value of the species.

\section{ACKNOWLEDGMENTS}

The author would like to express his gratitude to the National Research Foundation, South Africa (NRF) and Govan Mbeki Research and Development Centre (GMRDC), University of Fort Hare for financial support to conduct this study.

\section{CONFLICT OF INTEREST}

No conflict of interest is associated with this work.

\section{REFERENCES}

[1] Maroyi A. Options for the recovery of Warburgia salutaris (Pepperbark tree) populations in Zimbabwe. Zimbabwe Sci News 2000; 34: 54-60. http://dx.doi.org/10.4314/zsn.v34i3.18539

[2] Maroyi A. Ethnobotanical study of two threatened medicinal plants in Zimbabwe. Int J Biodiv Sci Manag 2008; 4: 148-53. https://doi.org/10.3843/Biodiv.4.3:2

[3] Maroyi A. Community attitudes towards the reintroduction programme for the endangered pepperbark tree Warburgia salutaris: implications for plant conservation in south-east Zimbabwe. Oryx 2012; 46: 213-8. https://doi.org/10.1017/S0030605311000767

[4] Maroyi A. Warburgia salutaris (Bertol. f.) Chiov.: a multi-use ethnomedicinal plant species. J Med PI. Res 2013; 7: 53-60. https://doi.org/10.5897/JMPR12.1019

[5] Maroyi A. The genus Warburgia: a review of its traditional uses and pharmacology. Pharmaceut Biol; 2014; 52: 378391 https://doi.org/10.3109/13880209.2013.837935

[6] Salatino A, Salatino MLF, et al. Traditional uses, chemistry and pharmacology of Croton species (Euphorbiaceae). J Brazilian Chem Soc 2007; 18(1): 11-33. http://dx.doi.org/10.1590/S0103-50532007000100002

[7] Kokwaro JO. Medicinal plants of East Africa. 2nd Edition. Nairobi: Kenya Literature Bureau; 1993

[8] Pakia M. Plant ecology and ethnobotany of two sacred forests (Kayas) at the Kenya coast. MSc Dissertation. Durban: University of Natal; 2000.

[9] Pakia M, Cooke JA. The ethnobotany of the Midzichenda tribes of the coastal forest areas in Kenya: 2. medicinal plant uses. S Afr J Bot 2003; 69(3): 382-95. https://doi.org/10.1016/S0254-6299(15)30321-5

[10] Kiringe JW. A survey of traditional health remedies used by the Maasai of southern Kaijiado district, Kenya. Ethnobot Res Appl 2006; 4: 61-73.

http://dx.doi.org/10.17348/era.4.0.61-74

[11] Lovett JC, Ruffo CK, et al. Field guide to the moist forest trees of Tanzania. York: Centre for Ecology Law and Policy, Environment Department, University of York; 2006.

[12] Gachathi M. A guide to plant names, uses and cultural values: Kikuyu botanical dictionary. Revised second edition. Nairobi: Tropical Botany; 2007.

[13] Schmelzer GH, Gurib-Fakim A. Plant resources of tropical Africa 11(1): Medicinal plants 1. Wageningen: PROTA Foundation; 2008.

[14] Ndunda B. Phytochemistry and bioactivity investigations of three Kenyan Croton species. PhD Thesis. Nairobi: University of Nairobi; 2014.
[15]

Ndunda B, Langat MK, et al. Alienusolin, a new 4adeoxyphorbol ester derivative, and crotonimide $\mathrm{C}$, a new glutarimide alkaloid from the Kenyan Croton alienus. PI Med 2013; 79: 1762-6.

http://doi.org/10.1055/s-0033-1351044

[16] Ndunda B, Langat MK, et al. New ent-clerodane and abietane diterpenoids from the roots of Kenyan Croton megalocarpoides Friis \& M. G. Gilbert. PI Med 2016; 82(11/12): 1079-86. http://dx.doi.org/10.1055/s-0042-108857

[17] Smith AR. Euphorbiaceae. In Polhill RM. (Ed.), Flora of tropical East Africa. Rotterdam: AA Balkema; 1987; pp. 20391.

[18] Beentje HJ. Atlas of the rare trees of Kenya. Utafiti 1988 1(3): 71-124.

[19] Radcliffe-Smith A. Euphorbiaceae. In Pope GV, Ed. Flora Zambesiaca: Mozambique, Malawi, Zambia, Zimbabwe and Botswana, volume 9(4). London: Kew Royal Botanic Gardens, Flora Zambesiaca Managing Committee; 1996; pp. 1-337.

[20] Oldfield S, Lusty C, et al. The world list of threatened trees. Cambridge: World Conservation Press; 1998.

[21] Watt JM, Breyer-Brandwijk MG, The medicinal and poisonous plants of southern and eastern Africa. London: Edinburgh: E and S Livingstone Ltd; 1962.

[22] Thulin M. Croton. In Thulin M, Ed. Flora of Somalia, volume 1. Pteridophyta, gymnospermae, angiospermae (Annonaceae-Fabaceae). London: Kew Royal Botanic Gardens; 1993; pp. 301-303.

[23] Mbwambo ZH, Foubert K, et al. New furanoditerpenoids from Croton jatrophoides. PI Med 2009; 75: 262-7. https://doi.org/10.1055/s-0028-1088383

[24] Magadula JJ, Innocent E, et al. Phytochemical and pharmacological studies of some medicinal plants from Tanzania. Int J Current Res Academic Review 2014; 2(10): 99-111.

[25] Kubo I, Hanke FJ, et al. Insect anti-feedant from tropical plants i. structure of dumsin. Tetrahedron 1990; 46: 1515-22.

[26] Nihei K, Hanke, et al. Insect anti-feedants from tropical plants ii: structure of zumsin. J Agric Food Chem 2002; 50: 504852 https://doi.org/10.1021/jf020245q

[27] Nihei K, Asaka $Y$, et al. Insect anti-feedants from tropical plants: structures of dumnin and dumsenin. J Agric Food Chem 2004: 52: 3325-8. https://doi.org/10.1021/jf049819c

[28] Nihei K, Asaka $Y$, et al. Insect anti-feedants from Croton jatrophoides: structure of zumketol, zumsenin and zumsenol. J Nat Prod 2005; 68: 244-7. https://doi.org/10.1021/np049697i

[29] Nihei K, Asaka Y, et al. Musidunin and musiduol, insect antifeedants from Croton jatrophoides. J Nat Prod 2006; 69: 9757. https://doi.org/10.1021/np060068d

[30] Chhabra SC, Thoruwa CL, et al. Phytochemical and biological studies of the genus Croton for the development of agrochemicals and pharmaceutical products. J Kenya Chem Soc 2007; 4(1): 33-45

[31] Zgoda-Pols JR, Freyer AJ, et al. Antimicrobial diterpene from the stem bark of Mitrephora celebica. Fitoterapia 2002; 73 : 434-8. https://doi.org/10.1016/S0367-326X(02)00124-7

[32] Hernández DM, Díaz-Ruiz G, et al. Ent-trachyloban-19-oic acid isolated from lostephane heterophylla as a promising antibacterial agent against Streptococcus mutans biofilms. Fitoterapia 2012; 83: 527-31. https://doi.org/10.1016/j.fitote.2011.12.022

[33] Gelaw H, Adane L, et al. Isolation of crotepoxide from berries of Croton macrostachyus and evaluation of its anti- 
leishmanial activity. J Pharmacogn Phytochem 2012; 1(4): 15-25.

[34] Nyasse B, Ngantchou I, et al. Antifilarial activity in vitro of polycarpol and 3-O-acetyl aleuritolic acid from Cameroonian medicinal plants against Onchocerca gutturosa. Nat Prod Res 2006; 20: 391-7. https://doi.org/10.1080/14786410600661377

[35] Tajebe F, Getahun M, et al. Disease severity in patients with visceral leishmaniasis is not altered by co-infection with intestinal parasites. PLoS Neglected Trop Dis 2017; 11(7): e0005727.

https://doi.org/10.1371/journal.pntd.0005727

[36] Kinyoda ABAM, Mwafaida JM, et al. Evaluation of Croton jatrophoides extract as a suppressant against Fusarium oxysporum f. sp. lycopersici in tomato. 16th Workshop on Sustainable Horticultural Production in the Tropics, Chuka University, Chuka, Kenya, 28th November - 2nd December 2016. 